\title{
Control of Brown Rot and Blue Mold of Sweet Cherry with Preharvest Iprodione, Postharvest Cryptococcus infirmo-miniatus, and Modified Atmosphere Packaging
}

\author{
R. A. Spotts, L. A. Cervantes, T. J. Facteau, and T. Chand-Goyal, Mid-Columbia Agricultural Research and Ex- \\ tension Center, Oregon State University, Hood River 97031
}

\begin{abstract}
Spotts, R. A., Cervantes, L. A., Facteau, T. J., and Chand-Goyal, T. 1998. Control of brown rot and blue mold of sweet cherry with preharvest iprodione, postharvest Cryptococcus infirmominiatus, and modified atmosphere packaging. Plant Dis. 82:1158-1160.

The effectiveness of preharvest iprodione and postharvest Cryptococcus infirmo-miniatus treatments alone and in combination for control of decay of sweet cherry fruit was studied. Also, the effect of a modified atmosphere on brown rot control was evaluated as a part of the iprodioneC. infirmo-miniatus combinations. A single preharvest application of iprodione at $1.13 \mathrm{~kg}$ a.i./ha reduced brown rot in stored sweet cherry fruit in both years of this study. Significantly better control of brown rot was obtained when cherry fruit that received a preharvest iprodione application also were treated with a postharvest dip in a suspension of $C$. infirmo-miniatus containing 0.5 to $1.5 \times 10^{8} \mathrm{CFU} / \mathrm{ml}$. Brown rot was reduced by modified atmosphere packaging (MAP) alone and further reduced as a result of a C. infirmo-miniatus-MAP synergism. Incidence of brown rot was reduced from $41.5 \%$ in the control to $0.4 \%$ by combining preharvest iprodione and postharvest $C$. infirmo-miniatus treatments with MAP.
\end{abstract}

Additional keywords: biocontrol, Monilinia fructicola, Penicillium expansum, Prunus, yeast

Approximately half of the market losses in Western sweet cherry fruit have resulted from disease (1). Several postharvest diseases, including blue mold (Penicillium expansum Link), brown rot (Monilinia fructicola G. Wint. Honey), Alternaria rot (Alternaria alternata (Fr.:Fr.) Keissl.), Rhizopus rot (Rhizopus stolonifer (Erhenb.:Fr.) Vuill.), and gray mold (Botrytis cinerea Pers.:Fr.), cause most of the decay (1). In a more recent survey, blue mold was the most damaging disease of sweet cherry at the New York terminal market and occurred in $35 \%$ of all shipments (2). Extended storage increases disease severity (17).

Postharvest disease control consists of an integrated combination of pre- and postharvest fungicide applications, sanitation, cold storage, and modified storage atmosphere $(28,30)$. While several fungicides can be used preharvest on sweet cherry, few postharvest fungicides are registered (23). Elevated atmospheric $\mathrm{CO}_{2}$ levels have been shown to reduce fruit decay of cherry during long-term storage $(10,12,19,20)$.

Corresponding author: R. A. Spotts

E-mail: robert.spotts@orst.edu

Current address of T. Chand-Goyal: U.S. Environmental Protection Agency, Washington, DC 20460.

Accepted for publication 2 July 1998.

Publication no. D-1998-0727-01R

(C) 1998 The American Phytopathological Society
Several recent studies have focused on biological control of postharvest diseases of stone fruits. Brown rot and Rhizopus rot of peach have been controlled with Bacillus subtilis (24) and Enterobacter cloacae (31), respectively. Bacillus subtilis also has controlled postharvest brown rot and Alternaria rot of sweet cherry (29). Control of brown rot of peach and nectarine has been achieved with Pseudomonas corrugata and $P$. cepacia when applied up to $12 \mathrm{~h}$ after inoculation with the pathogen (27). Application of Aureobasidium pullulans and Epicoccum purpurascens to sweet cherry blossoms reduced the number of latent infections of brown rot in green fruit (32). Candida oleophila reduced the level of infection caused by $P$. expansum in harvested nectarines (15). C. oleophila was effective in air and controlled atmosphere storage and when combined with the fungicide dichloran (15).

Recently, we found that three naturally occurring, saprophytic yeasts isolated from the surface of pear fruit (5) were effective for control of five postharvest diseases of pear $(3,6)$. In addition, these yeasts controlled blue mold of apple and brown rot of sweet cherry fruit $(4,6)$. Control of brown rot of sweet cherry was achieved when a combination of Cryptococcus laurentii or C. infirmo-miniatus with a low dose of iprodione was applied postharvest (4). Iprodione was used extensively as a postharvest treatment of cherry until March 1996, when the product label was voluntarily changed by the manufacturer to cancel postharvest use on sweet cherry and to restrict applications to no fewer than 7 days before harvest.

The primary objective of this study was to determine the effectiveness of preharvest iprodione and postharvest $C$. infirmominiatus ( $\mathrm{Cim})$ treatments alone and in combination for control of decay of sweet cherry fruit. In addition, the effect of a postharvest modified atmosphere storage on brown rot control was evaluated as a part of the iprodione-Cim combinations.

\section{MATERIALS AND METHODS}

Iprodione (Rovral 50WP, RhonePoulenc Ag Co., Research Triangle Park, NC) was applied to five sweet cherry trees cv. Lambert on 21 or 28 June 1996 and 20 June 1997. Iprodione was applied at the rate of $1.13 \mathrm{~kg}$ a.i./ha in 757 liters of water (7.57 liters per tree) using a handgun sprayer operating at a pressure of 21 $\mathrm{kg} / \mathrm{cm}^{2}$. Five nonsprayed trees were left as controls. In 1996, all trees were sprayed with chlorothalonil at $2.36 \mathrm{~kg}$ a.i./ha on 8 and 15 April and 28 May. In 1997, all trees received bloom applications of chlorothalonil at 1.70 and $1.18 \mathrm{~kg}$ a.i./ha on 15 and 24 April, respectively.

Healthy appearing sweet cherry fruits were harvested on 3 July 1996 and 27 June 1997 at commercial maturity and treated the day of harvest. Cherry fruits were neither wounded nor surface-sterilized.

C. infirmo-miniatus strain YY6, isolated from the surface of a pear fruit from Yakima, Washington, in 1993 (5), was stored at $-70^{\circ} \mathrm{C}$ using the procedure of Gibson and Khoury (13). This yeast was activated by dispensing $70 \mu \mathrm{l}$ of thawed suspension into $70 \mathrm{ml}$ of yeast malt dextrose broth (YMDB: $3.0 \mathrm{~g}$ of Bacto yeast extract, $3.0 \mathrm{~g}$ of Difco malt extract, $5.0 \mathrm{~g}$ of Bacto peptone, and $10.0 \mathrm{~g}$ of Bacto dextrose per liter of medium) in a 200-ml flask. The Cim suspension was incubated on a rotary shaker at $125 \mathrm{rpm}$ for $48 \mathrm{~h}$ at 23 $\pm 1^{\circ} \mathrm{C}$, then spread $(0.1 \mathrm{ml}$ per petri dish $)$ on yeast malt dextrose agar (YMDA) medium (YMDB plus $18.0 \mathrm{~g}$ of Bacto agar per liter). After $48 \mathrm{~h}$ of incubation at $23 \pm$ $1^{\circ} \mathrm{C}, \mathrm{Cim}$ cells were removed with a sterile rubber spatula, suspended in sterile distilled water (SDW), and vortexed for 1 to 3 $\min$. The Cim cells were centrifuged at 1.0 $\times 10^{4} \mathrm{rpm}\left(\mathrm{G}=1.06 \times 10^{4}\right)$ for $15 \mathrm{~min}$, and the supernatant was discarded. The cells were resuspended in SDW, and the concentration was adjusted to $1.45 \times 10^{8}$ $\mathrm{CFU} / \mathrm{ml}$ in 1996 and $0.47 \times 10^{8} \mathrm{CFU} / \mathrm{ml}$ in 
1997 (2\% transmittance at $550 \mathrm{~nm}$ using model Spectronic 20 spectrophotometer, Bausch and Lomb Optical Co., Rochester, NY). Yeast concentration was verified by dilution plating on YMDA.

In 1996, conidia of $M$. fructicola were harvested into SDW from a 12-day-old culture grown on acidified PDA. In 1997, conidia were removed from infected cherry fruit in the orchard by vigorously scraping fruit in SDW with a rubber spatula. Germination of conidia was $94 \%$. In both years, spore concentrations were determined with a hemacytometer and adjusted to $1.0 \times 10^{4}$ conidia per $\mathrm{ml}$ of treatment suspension; suspensions were used within 2 to $3 \mathrm{~h}$.

The postharvest treatments applied to sweet cherry fruits were: $M$. fructicola alone (control) and Cim combined with $M$. fructicola. These treatments were applied to fruit from each of the three preharvest treatment regimes (no spray and iprodione at 12 or 5 days preharvest) in 1996 and two regimes (no spray and iprodione at 7 days preharvest) in 1997. There were five replicates of 50 cherry fruits in each preharvest-postharvest treatment combination. Fruits were placed in containers with metal screens, immersed for $30 \mathrm{~s}$ in treatment suspensions, then drained for $1 \mathrm{~min}$.

Each replicate of 50 fruits was stored in air at $2.8^{\circ} \mathrm{C}$ in a 3.78 -liter polyethylene bag that had 18 6-mm-diameter holes along three sides. Twenty of these bags were placed into a larger folded but unsealed polyethylene bag inside a cardboard cherry box. In 1997, five replicate bags per treatment also were stored in a modified atmosphere package (MAP) sold under the trademark View Fresh (Orchard View Farms, The Dalles, OR), a polyethylene bag whose exact characteristics are proprietary. Prior to storage at $0.5^{\circ} \mathrm{C}$, the bag was evacuated, injected with a 50-50 gas mix of $\mathrm{CO}_{2}$ and $\mathrm{N}_{2}$, and sealed using a CVP Systems gas injection system (Model A-300, Dowensgrove, IL). The atmosphere of the bag was determined by gas chromatography just prior to opening for fruit evaluation after 42 days of storage, and the percentages of oxygen and carbon dioxide were 5.1 and 11.4 , respectively. Disease incidence was evaluated after 20 and 42 days storage in air and MAP, respectively.

In 1996, iprodione residues that washed off the fruit into the postharvest treatment suspension were determined by enzymelinked immunosorbent assay (ELISA) using a Carbaryl RaPID Assay kit (Ohmicron, Newtown, PA) modified for iprodione. Iprodione residue in the suspensions in which the fruit were dipped was $2.2 \pm$ $0.6 \mu \mathrm{g} / \mathrm{ml}$.

In 1997, iprodione residues on fruit and in treatment suspensions were determined by gas liquid chromatography by Horizon Laboratories, Columbia, Missouri. The mean and standard error of the iprodione residue on the surface of fruit from trees sprayed with iprodione was $2.2 \pm 0.3 \mu \mathrm{g} / \mathrm{g}$.
Iprodione residues on fruit from unsprayed trees and in water after dipping all fruit from unsprayed trees was less than 0.05 $\mu \mathrm{g} / \mathrm{g}$, the minimum detectable amount. Iprodione residue in water after dipping all fruit from both unsprayed and iprodionetreated trees was $2.6 \mu \mathrm{g} / \mathrm{ml}$.

\section{RESULTS AND DISCUSSION}

In 1996, rain occurred on 18, 19, 23, 24, and 25 June as cherry fruit ripened and caused splitting in about $95 \%$ of the fruit. Although the tissue at the split areas appeared to dry, considerable blue mold from natural inoculum and brown rot from controlled inoculation developed in this tissue. All treatments reduced blue mold, and all except $\mathrm{Cim}$ alone reduced brown rot (Table 1). C. infirmo-miniatus combined with iprodione applied 5 days before harvest (PHI) was significantly better than the 12day PHI iprodione alone (blue mold and brown rot) and the 5-day PHI iprodione alone (brown rot). C. infirmo-miniatus combined with the 12-day PHI iprodione was not different from the 5-day iprodione alone or the Cim combined with the 5-day PHI iprodione for both blue mold and brown rot.

For air-stored fruit in 1997, iprodione and the combination of preharvest iprodione with postharvest Cim reduced brown rot incidence, but Cim alone had no effect when compared with the control (Table 2). Untreated fruit stored for 42 days under MAP conditions had $40 \%$ less brown rot than those stored for 20 days in refrigerated air (Table 2). For MAP-stored fruit, both the iprodione and the Cim treatments alone significantly reduced brown rot incidence (Table 2). The combination of the iprodione and Cim was more effective than iprodione alone.

Preharvest applications of iprodione are effective for control of postharvest brown rot fruit decay and have been recommended for several years in the Pacific Northwest (23). A single preharvest application of iprodione reduced brown rot in stored sweet cherry fruit in both years of this study. Dicarboximides such as iprodione inhibit the germination of conidia as well as mycelial growth (26). Sensitive strains of $M$. fructicola are affected by less than $1 \mu \mathrm{g}$ of iprodione per $\mathrm{ml}(8)$. Iprodione residues in water or yeast suspensions in which cherry fruit were dipped ranged from 2.2 to $2.6 \mu \mathrm{g} / \mathrm{ml}$ in 1996 and 1997 , respectively. Although the resistance status of strains of $M$. fructicola used in this study was not determined, it appears that most were sensitive to iprodione, since the fungicide gave significant $(P=0.05)$ decay control.

Table 1. Control of decay of sweet cherry fruit with combinations of preharvest iprodione and postharvest Cryptococcus infirmo-miniatus applications in 1996

\begin{tabular}{|c|c|c|}
\hline \multirow[b]{2}{*}{ Treatment $^{\mathrm{x}}$} & \multicolumn{2}{|c|}{ Percent fruits decayed $^{w}$} \\
\hline & Blue mold ${ }^{y}$ & Brown $\operatorname{rot}^{\mathrm{z}}$ \\
\hline C. infirmo-miniatus & $4.0 \mathrm{~b}$ & $16.0 \mathrm{de}$ \\
\hline C. infirmo-miniatus + iprodione 5 day PHI & $0.0 \mathrm{a}$ & $2.4 \mathrm{a}$ \\
\hline C. infirmo-miniatus + iprodione 12 day PHI & $0.0 \mathrm{a}$ & $3.2 \mathrm{ab}$ \\
\hline Iprodione 5 day PHI & $2.4 \mathrm{ab}$ & $6.8 \mathrm{bc}$ \\
\hline Iprodione 12 day PHI & $4.4 \mathrm{~b}$ & $8.4 \mathrm{~cd}$ \\
\hline Nontreated & $19.6 \mathrm{c}$ & $20.8 \mathrm{e}$ \\
\hline
\end{tabular}

${ }^{\mathrm{w}}$ Mean disease incidences for five replicate, 50 -fruit samples per treatment. Means followed by the same letter within columns are not significantly different at $P=0.05$ according to least significant difference (LSD) test. Data were transformed to arcsine $\sqrt{\text { percent }}$ before analysis.

${ }^{x}$ Aqueous suspensions of $C$. infirmo-miniatus contained $1.45 \times 10^{8} \mathrm{CFU} / \mathrm{ml}$. Iprodione was applied 5 and 12 days before harvest (PHI) at $1.13 \mathrm{~kg}$ a.i./ha.

y Blue mold developed from natural inoculum.

${ }^{\mathrm{z}}$ Postharvest treatment suspensions (C. infirmo-miniatus and sterile distilled water) contained $1 \times$ $10^{4}$ conidia of Monilinia fructicola per ml.

Table 2. Effect of preharvest iprodione, postharvest Cryptococcus infirmo-miniatus, and modified atmosphere packaging on control of brown rot of sweet cherry fruit

\begin{tabular}{lcc}
\hline & \multicolumn{2}{c}{ Percent decay $^{\mathbf{w}, \mathbf{x}}$} \\
\cline { 2 - 3 } Treatment, $\mathbf{z}$ & Air & Modified atmosphere $^{\mathbf{n}}$ \\
\hline C. infirmo-miniatus & $41.3 \mathrm{e}$ & $2.0 \mathrm{abc}$ \\
C. infirmo-miniatus + iprodione & $1.2 \mathrm{ab}$ & $0.4 \mathrm{a}$ \\
Iprodione & $2.0 \mathrm{abc}$ & $4.8 \mathrm{c}$ \\
Nontreated & $41.5 \mathrm{e}$ & $24.7 \mathrm{~d}$ \\
\hline
\end{tabular}

${ }^{\mathrm{w}}$ Decay evaluated after 20 and 42 days storage in air at $2.8^{\circ} \mathrm{C}$ or modified atmosphere $(5.1 \%$ oxygen, $11.4 \%$ carbon dioxide) at $0.5^{\circ} \mathrm{C}$, respectively.

${ }^{x}$ Mean disease incidences of five replicate, 50-fruit samples per treatment. Means followed by the same letter are not significantly different according to least significant difference (LSD) test at $P=$ 0.05. Data were transformed to arcsine $\sqrt{\text { percent }}$ before analysis.

${ }^{y}$ Aqueous suspensions of $C$. infirmo-miniatus contained $0.47 \times 10^{8} \mathrm{CFU} / \mathrm{ml}$. Iprodione was applied 7 days before harvest at $1.13 \mathrm{~kg} / \mathrm{ha}$.

${ }^{\mathrm{z}}$ Postharvest treatment suspensions (C. infirmo-miniatus and sterile distilled water) contained $1 \times$ $10^{4}$ conidia of Monilinia fructicola per ml. 
Significantly better control of brown rot usually was obtained when cherry fruit that received a preharvest iprodione application also were treated postharvest with Cim. Whereas residues of iprodione in this study were adequate to affect $\mathrm{M}$. fructicola, Cim is resistant to $50 \mu \mathrm{g}$ iprodione/ml in YMDA (T. Chand-Goyal, unpublished). In previous studies with pome fruits, three yeasts, including $\mathrm{Cim}$, combined with 15 $\mu \mathrm{g}$ of thiabendazole per $\mathrm{ml}$ gave significantly better disease control than either thiabendazole or the yeasts alone $(3,4)$.

Although $C$. infirmo-miniatus alone did not control brown rot in air-stored cherry fruit, the yeast alone did control blue mold caused by $P$. expansum. While conidia of $M$. fructicola germinate in less than $30 \mathrm{~h}$ at $0^{\circ} \mathrm{C}, P$. expansum conidia do not germinate in $96 \mathrm{~h}$ at this temperature (11). The slower germination rate of $P$. expansum may give Cim time to grow and colonize wound sites. In previous studies with biocontrol of blue mold of apple and pear, Cim rapidly colonized wound sites and appeared to control decay by competition for nutrients $(3,4)$.

Brown rot also was reduced by MAP storage. The $\mathrm{CO}_{2}$ level in the MAP was $11.5 \%$ after 42 days of storage. In previous studies, decay of sweet cherry has been reduced by $\mathrm{CO}_{2}$ atmospheres of 7.5 to $25 \%$ $(10,12,19,20)$. Carbon dioxide is considered fungistatic to $M$. fructicola, since decay develops when fruit are returned to air $(7,9)$. Many yeasts require $\mathrm{CO}_{2}$ as a carbon source for growth (25), and about $10 \% \mathrm{CO}_{2}$ enhances sporulation in yeast fungi (22). In addition, when $\mathrm{CO}_{2}$ dissolves in water, carbonic acid is produced and $\mathrm{pH}$ is lowered. Lower $\mathrm{pH}$ has been reported to favor yeast fungi (21), and Cim will grow in wounds of freshly harvested Golden Delicious apple at $\mathrm{pH} 3.1$ (T. Chand-Goyal, unpublished). Thus, the Cim-MAP synergism for control of brown rot may be related to a combination of suppression of $M$. fructicola and stimulation of $\mathrm{Cim}$ by the high $\mathrm{CO}_{2}$. In a recent study with d'Anjou pear fruit, the combination of $\mathrm{Cim}$ and MAP ( 2 to $6 \% \mathrm{O}_{2}, 0.5$ to $1 \% \mathrm{CO}_{2}$ ) reduced blue mold better than MAP without yeast or treatment with $\mathrm{Cim}$ followed by storage in air (16).

In recent years, an integrated strategy to control decay in pome and stone fruits has been advanced $(28,30)$. In this study, the combination of preharvest iprodione with postharvest $\mathrm{Cim}$ reduced decay by 88.5 to $97.1 \%$, and fruit treated with this combination and stored in modified atmosphere packaging had a reduction in brown rot of $98.2 \%$. The cherry industry is interested in reduction of decay by nonchemical means and maintenance of fruit quality during long-term storage and distant transport. In many instances, slower surface transportation is used rather than faster but more expensive air transport. Implementation of the preharvest iprodione-postharvest yeastMAP system would increase decay control during long-term storage and transport of sweet cherry fruit.

\section{ACKNOWLEDGMENTS}

We thank Rhone-Poulenc Ag Company for arranging for iprodione residue analysis in 1997. Use of trade names in this article does not imply endorsement by Oregon State University of the products named or criticism of similar products not mentioned. Oregon Agricultural Experiment Station technical paper 11336

\section{LITERATURE CITED}

1. Ceponis, M. J., and Butterfield, J. E. 1981. Cull losses in Western sweet cherries at retail and consumer levels in metropolitan New York. HortScience 16:324-326.

2. Ceponis, M. J., Cappellini, R. A., and Lightner, G. W. 1987. Disorders in sweet cherry and strawberry shipments to the New York market, 1972-1984. Plant Dis. 71:472-475.

3. Chand-Goyal, T., and Spotts, R. A. 1996. Control of postharvest pear diseases using natural saprophytic yeast colonists and their combination with a low dosage of thiabendazole. Postharvest Biol. Technol. 7:51-64.

4. Chand-Goyal, T., and Spotts, R. A. 1996. Postharvest biological control of blue mold of apple and brown rot of cherry by natural saprophytic yeasts alone or in combination with low doses of fungicides. Biol. Control 6:253259.

5. Chand-Goyal, T., and Spotts, R. A. 1996. Enumeration of bacterial and yeast colonists of apple fruits and identification of epiphytic yeasts on pear fruits in the Pacific Northwest United States. Microbiol. Res. 151:427-432.

6. Chand-Goyal, T., and Spotts, R. A. 1997. Biological control of postharvest diseases of apple and pear under semi-commercial and commercial conditions using three saprophytic yeasts. Biol. Control 10:199-206.

7. De Vries-Paterson, R. M., Jones, A. L., and Cameron, A. C. 1991. Fungistatic effects of carbon dioxide in a package environment on the decay of Michigan sweet cherries by Monilinia fructicola. Plant Dis. 75:943-946.

8. Elmer, P. A. G., and Gaunt, R. E. 1994. The biological characteristics of dicarboximideresistant isolates of Monilinia fructicola from New Zealand stone-fruit orchards. Plant Pathol. 43:130-137.

9. English, H., and Gerhardt, F. 1942. Effect of carbon dioxide and temperature on the decay of sweet cherries under simulated transit conditions. Pro. Am. Soc. Hortic. Sci. 40:172176.

10. Gerhardt, F., English, H., and Smith, E. 1942. Respiration, internal atmosphere, and moisture studies of sweet cherries during storage. Proc. Am. Soc. Hortic. Sci. 41:119-123.

11. Gerhardt, F., English, H., and Smith, E. 1945. Cracking and decay of bing cherries as related to the presence of moisture on the surface of the fruit. Proc. Am. Soc. Hortic. Sci. 46:191198.

12. Gerhardt, F., and Ryall, A. L. 1939. The storage of sweet cherries as influenced by carbon dioxide and volatile fungicides. U.S. Dep. Agric. Tech. Bull. 631.

13. Gibson, L. F., and Khoury, J. T. 1986. Storage and survival of bacteria by ultra-freeze. Let. Appl. Microbiol. 3:127-129.

14. Kupferman, E., and Waelti, H. 1992. Management practices to minimize postharvest decay of cherries. Tree Fruit Postharvest J. $3: 14$.

15. Lurie, S., Droby, S., Chalupowicz, L., and Chalutz, E. 1995. Efficacy of Candida oleophila strain 182 in preventing Penicillium expansum infection of nectarine fruits. Phytoparasitica 23:231-234.

16. Miller, M., and Sugar, D. 1997. Modified atmosphere packaging and its applications in storage, decay control, and marketing pears. Pages 277-284 in: Proc. Int. Controlled Atmosphere Res. Conf. E. J. Mitcham, ed. University of California, Davis.

17. Ogawa, J. M. 1995. Miscellaneous postharvest fruit decay. Page 17 in: Compendium of Stone Fruit Diseases. J. M. Ogawa, E. I. Zehr, G. W. Bird, D. F. Ritchie, K. Uriu, and J. K. Uyemoto, eds. American Phytopathological Society, St. Paul, MN.

18. Ogawa, J. M., and English, H. 1991. Diseases of temperate zone tree fruit and nut crops. University of California, Division of Agriculture and Natural Resources, Oakland.

19. Patterson, M. E. 1982. CA storage of cherries. Oreg. State Univ. School Agric. Sympos. Ser. 1:149-154.

20. Patterson, M. E., and Guelich, K. 1989. CA storage of Rainier cherries. Pages 228-230 in: Proc. Annu. Mtg. Wash. State Hortic. Assoc., 85th.

21. Pederson, C. S., Alburg, M. N., and Christensen, M. D. 1961. The growth of yeasts in grapefruit juice stored at low temperature. IV. Fungistatic effects of organic acids. Appl. Microbiol. 9:162-167.

22. Powell, R. R. 1969. Sporulation and hybridization of yeasts. Pages 303-383 in: The Yeasts. A. H. Rose and J. S. Harrison, eds. Academic Press, London.

23. Pscheidt, J. W., and Ocamb, C. M. 1998 Cherry brown rot blossom blight and fruit rot. Pages 87-88 in: Pacific Northwest Plant Disease Control Handbook. OSU Extension Service.

24. Pusey, P. L., and Wilson, C. L. 1984. Postharvest biological control of stone fruit brown rot by Bacillus subtilis. Plant Dis. 68:753-756.

25. Rockwell, G. F., and Highberger, J. H. 1927. The necessity of carbon dioxide for the growth of bacteria, yeasts, and molds. J. Infect. Dis. 40:38-46.

26. Sisler, H. D. 1988. Dicarboximide fungicides: Mechanisms of action and resistance. Page 52 in: Fungicide Resistance in North America. C. J. Delp, ed. American Phytopathological Society, St. Paul, MN

27. Smilanick, J. L., Denis-Arrue, R., Bosch, J. R., Gonzalez, A. R., Henson, D., and Janisiewicz, W. J. 1993. Control of postharvest brown rot of nectarines and peaches by PSeudomonas species. Crop Prot. 12:513-520.

28. Sugar, D., Roberts, R. G., Hilton, R. J. Righetti, T. L., and Sanchez, E. E. 1994. Integration of cultural methods with yeast treatment for control of postharvest fruit decay in pear. Plant Dis. 78:791-795.

29. Utkhede, R. S., and Sholberg, P. L. 1986. In vitro inhibition of plant pathogens by Bacillus subtilis and Enterobacter aerogenes and in vivo control of two postharvest cherry diseases. Can. J. Microbiol. 32:963-967.

30. Willett, M., Kupferman, E., Roberts, R., Spotts, R., Sugar, D., Apel, G., Ewart, W., and Bryant, B. 1989. Integrated management of the postharvest diseases and disorders of apples, pears, and cherries. Postharvest Pomology Newsl. 7:1-16.

31. Wilson, C. L., Franklin, J. D., and Pusey, P. L. 1987. Biological control of Rhizopus rot of peach with Enterobacter cloacae. Phytopathology 77:303-305.

32. Wittig, H. P. P., Johnson, K. B., and Pscheidt, J. W. 1997. Effect of epiphytic fungi on brown rot blossom blight and latent infections in sweet cherry. Plant Dis. 81:383-387. 